\title{
Trinuclear Gold-Carborane Cluster as a Host Structure
}

\author{
Gabriel Aullón, ${ }^{(a)}$ Antonio Laguna, ${ }^{(b)}$ Oleg A. Filippov ${ }^{(c)}$, Josep M. Oliva-Enrich ${ }^{(d)}$ \\ (a) Departament de Química Inorgànica i Orgànica (secció Química Inorgànica), and Institut de \\ Química Teòrica i Computacional (IQTCUB), Universitat de Barcelona, 08028 Barcelona, \\ Spain
}

(b) Departamento de Química Inorgánica, Instituto de Ciencia de Materiales de Aragón, Universidad de Zaragoza-CSIC, 50009 Zaragoza, Spain

(c) A. N. Nesmeyanov Institute of Organoelement Compounds, Russian Academy of Sciences, Vavilova str. 28, 119991 Moscow, Russia

(d) Instituto de Química-Física "Rocasolano", Consejo Superior de Investigaciones Científicas (CSIC), 28006 Madrid, Spain

Dr. Gabriel Aullón, gabriel.aullon@qi.ub.edu ,www.ee.ub.edu

Prof. Dr. Antonio Laguna, alaguna@unizar.es, www.isqch.unizar-csic.es

Dr. Oleg A. Filippov, bigret@gmail.com, www.mhlab.ru

Dr. Josep M. Oliva-Enrich, j.m.oliva@iqfr.csic.es ,www.iqfr.csic.es

\begin{abstract}
This work encompasses a comprehensive study of host $\cdots$ guest interactions between cyclic trimer metal-carborane $\left[\mathrm{Au}_{3}\left(1,2-\mathrm{C}_{2} \mathrm{~B}_{10} \mathrm{H}_{10}\right)_{3}\right]^{3-}$, and several guest species as cations $\left(\mathrm{H}^{+}, \mathrm{Li}^{+}, \mathrm{Be}^{2+}, \mathrm{Hg}^{2+}\right)$, anions $\left(\mathrm{F}^{-}, \mathrm{H}^{-}, \mathrm{Cl}^{-}, \mathrm{Br}^{-}, \mathrm{I}^{-}, \mathrm{HCC}^{-}\right)$, and neutral molecules $\left(\mathrm{H}_{2}, \mathrm{CO}_{2}, \mathrm{I}_{2}, \mathrm{HCCH}, \mathrm{N}_{2}\right)$. A computational study has been carried out in order to evaluate energetic profiles and determine the contribution for attractive or repulsive interactions between guest and host. Several cases call our attention as a function of the energy minima. For instance, all above cations form stable minima as guest complexes with the three gold atoms of the host. Unexpectedly, pyramidal $\mathrm{H}^{-}$or $\mathrm{F}^{-}$species are obtained as energy minima, while other anions give completely repulsive interactions. Finally, the $\mathrm{CO}_{2}$ molecule is also trapped inside the trinuclear ring.
\end{abstract}




\section{Introduction}

Molecular architectures containing transition metals play an important role in the design of new structures with desired properties. ${ }^{[1]}$ Since gold is a good candidate to lead a wide variety of molecular constructs, the most stable Au(I) oxidation state can provide rich coordination environments. ${ }^{[2]}$

The icosahedral 1,2-closo- $\mathrm{C}_{2} \mathrm{~B}_{10} \mathrm{H}_{10}$ carborane exhibits large chemical, electrochemical and thermal stabilities, and is attractive for a wide range of direct and potential applications. ${ }^{[3,4]}$ Upon deprotonation of the carbon atoms, highly nucleophilic carbanions are generated, and synthetic efforts have led in the last decades to a large variety of structures incoporating transition-metal atoms. ${ }^{[5]}$ The combination of icosahedral carboranes and $\mathrm{Au}(\mathrm{I})$ with $\sigma \mathrm{Au}-\mathrm{C}$ bonds has been reported in the literature. ${ }^{[6]}$ Ortho-carborane cages act as bridging ligands forming triangular cyclic structures $\left[\mathrm{Au}_{3} \mathrm{Cage}_{3}\right]^{3-}\left(\mathrm{Cage}=1,2-\right.$ closo $-\mathrm{C}_{2} \mathrm{~B}_{10} \mathrm{H}_{10}$, Figure 1), with non-bonded $\mathrm{Au} \cdots \mathrm{Au}$ distances of $3.78 \AA \AA^{[7]}$ Moreover, gold clusters may exhibit luminescence, and the combination with carborane cages provides highly emissive systems. ${ }^{[8]}$

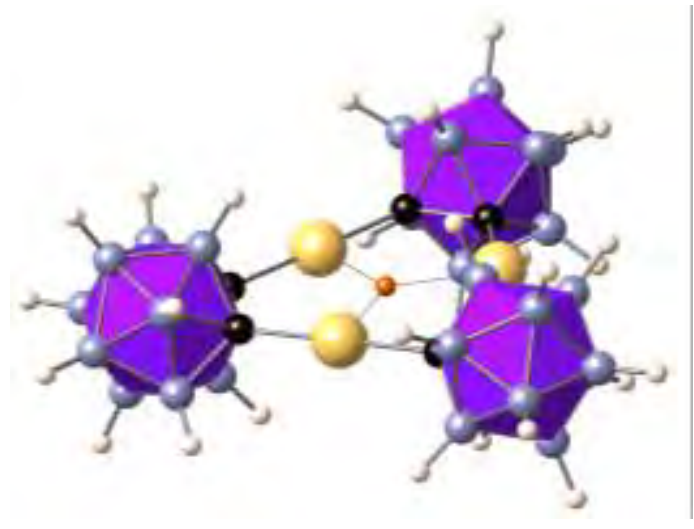

Figure 1. Trinuclear cyclic structure for the $\left[\left\{\mathrm{Au}_{3} \mathrm{Cage}_{3}\right\}\right]^{3-}$ complex. The centroid of the gold atoms is taken as reference $(z=0)$. Hydrogen atoms are displayed in this figure, but removed in the following figures in order to ease visualization of the molecular structures.

The triangular cyclic $\left[\mathrm{Au}_{3} \mathrm{Cage}_{3}\right]^{3-}$ structures present a cavity in the ring with a distance about $2.18 \AA$ from gold to the centroid, where some species could be embedded. ${ }^{[7]}$ Surprisingly, no such adduct has been reported to date despite the the void should allow binding of molecules. We have focused on the capability of the $\left[\mathrm{Au}_{3} \mathrm{Cage}_{3}\right]^{3-}$ host to form adducts with different guest systems: cations, anions or neutral molecules. We have performed a computational study to estimate the relative stabilities and geometries of the final compounds. 


\section{Methodology}

Density Functional Therory computations were carried out using the Gaussian09 package. ${ }^{[9]}$ The hybrid DFT method known as B3LYP was applied, in which the Becke three parameters exchange functional and the Lee-Yang-Parr correlation functional were used. ${ }^{[10]}$ Effective core potentials were used to represent the innermost electrons of the transition metal atoms ( $\mathrm{Au}$ and $\mathrm{Hg}$ ) and the associated basis set of valence double- $\zeta$ quality known as LANL2DZ. ${ }^{[11]}$ The basis set for the main elements was also of double$\zeta$ split-valence quality with polarization functions on non-hydrogen atoms (known as 6$\left.31 \mathrm{G}^{*}\right),{ }^{[12]}$ while for iodine we used the effective core potentials. ${ }^{[13]}$

In order to obtain the energetic profiles, the guest molecule (with frozen geometry) was inserted along the vertical axis $z$, as shown in Figure 1. The centroid of gold triangle was taken as reference as $z=0$ for single atoms, while relative position of the center of mass for polyatomic guests was considered. After the energy profiles versus $z$ were computed, we relaxed the host-guest geometry in order to obtain unconstrained stationary points, which were confirmed as energy minima by means of vibrational analysis.

\section{Results and Discussion}

(a) Cations: Given the anionic nature of the trinuclear gold host, cations are considered as good candidates for stable host $\cdots$ guest complexes. ${ }^{[7]}$ In this case, we have selected the following cations: $\mathrm{H}^{+}, \mathrm{Li}^{+}, \mathrm{Be}^{2+}$ and $\mathrm{Hg}^{2+}$. The energetic profile for cations as a function of the distance to the centroid of the gold host is presented in Figure 2.

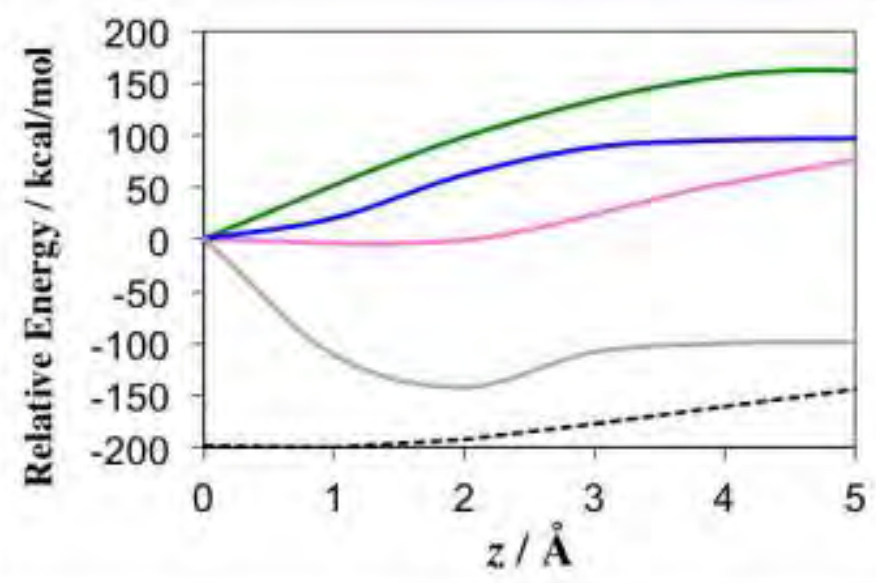

Figure 2. Energy profiles of host $\cdots$ guest interaction between $\left[\mathrm{Au}_{3} \mathrm{Cage}_{3}\right]^{3-}$ with different cations: $\mathrm{Be}^{2+}$, $\mathrm{H}^{+}, \mathrm{Li}^{+}$, and $\mathrm{Hg}^{2+}$. The electrostatic potential along $z$ is represented with a dashed line. 
An attractive interaction with cations such as $\mathrm{Be}^{2+}, \mathrm{Li}^{+}$and $\mathrm{H}^{+}$can be found at $z=0$ from Figure 2. The energy mínimum for $\mathrm{Be}^{2+}$ as a guest, $\left[\left\{\mathrm{Au}_{3} \mathrm{Cage}_{3}\right\}(\mathrm{Be})\right]^{-}$, appears in the centroid of the gold triangle $(z=0)$ with Au-Be distances of $2.17 \AA$ (Figure 3a), which fits within the size of the cavity. ${ }^{[7]}$ Similarly, the mínimum for the $\mathrm{H}^{+}$guest, $\left[\left\{\mathrm{Au}_{3} \mathrm{Cage}_{3}\right\}(\mathrm{H})\right]^{2-}$, is also expected to be in the centroid, but the reoptimization of the molecular geometry at $z=0$ gives an asymmetric structure with the proton moved from the centroid away from one gold atom (2.97 $\AA$ ) formimg two Au-H bonds at $1.77 \AA$, with an angle $\mathrm{Au}-\mathrm{H}-\mathrm{Au}=153^{\circ}$ (Figure $3 \mathrm{~b}$ ). Since $\mathrm{Li}^{+}$presents a very smooth energy profile (less than $0.3 \mathrm{kcal} / \mathrm{mol}$ ) from $z=0$ up to $2 \AA$, the complex $\left[\left\{\mathrm{Au}_{3} \mathrm{Cage}_{3}\right\}(\mathrm{Li})\right]^{2-}$ has been reoptimized. The new structure is minimized at $z=1.2 \AA$ generating a $\mathrm{C}_{3 \mathrm{v}}$ piramidal structure for $\mathrm{Li}^{+}$(Figure 3c) with Au-Li distances of $2.52 \AA$.

The ionic nature of host and guest fragments induces an important electrostatic contribution in the stability of these species. As an example, the larger interaction for $\mathrm{Be}^{2+}$ than $\mathrm{Li}^{+}$or $\mathrm{H}^{+}$is due to the charge of cationic guests (about 162, 123 and 97 $\mathrm{kcal} / \mathrm{mol}$, respectively). However, the electrostatical potential is also represented in Figure 2 as a dashed line, suggesting that these values can not be explained only by electrostatic interaction and hence other factors should contribute to the host $\cdots$ guest interactions. The $\mathrm{Au}-\mathrm{Be}$ and $\mathrm{Au}-\mathrm{Li}$ distances are intermediate between the sum of covalent $(2.32 \text { and } 2.64 \AA)^{[14]}$ and ionic radii (1.92 and 2.41 $\left.\AA\right)$, ${ }^{[15]}$ while Au-H distance is close to covalent interaction (1.67 $\AA$ ). 


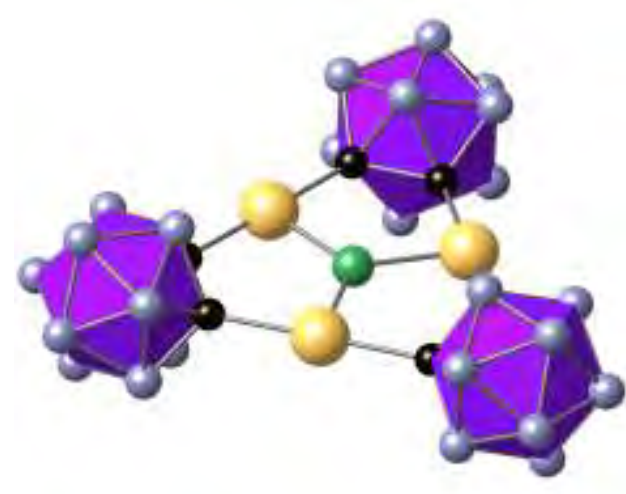

(a)

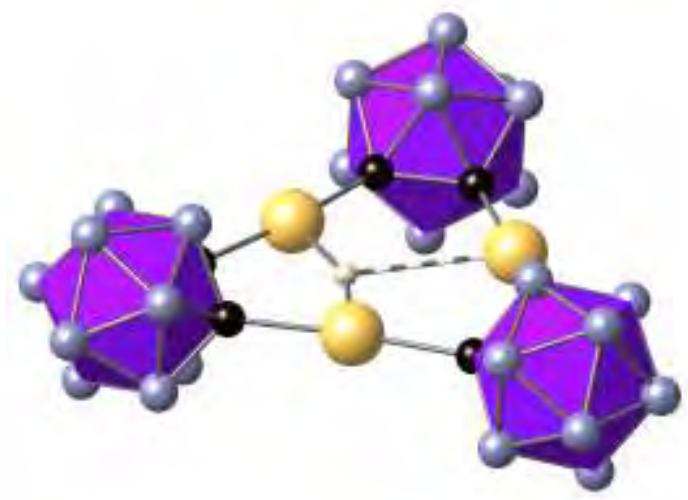

(b)

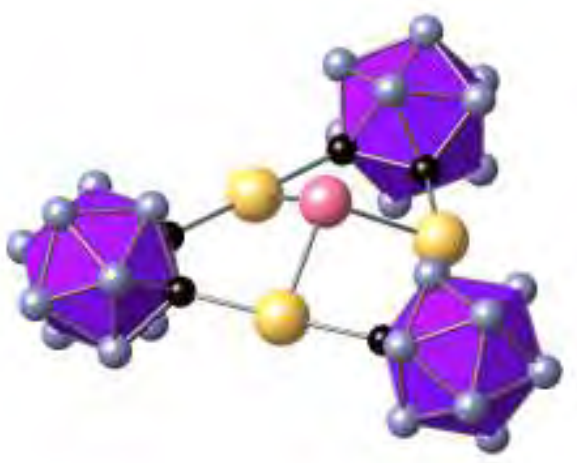

(c)

Figure 3. Optimized geometries for the $\left[\left\{\mathrm{Au}_{3} \mathrm{Cage}_{3}\right\}(\mathrm{G})\right]^{3-}$ compounds, having $\mathrm{G}$ cations such as $(a)$ $\mathrm{Be}^{2+},(b) \mathrm{H}^{+}$, and $(c) \mathrm{Li}^{+}$, respectively.

Due to the ease of formation for $\mathrm{Au}$ and $\mathrm{Hg}$ complexes with metallophilic interactions, ${ }^{[16]}$ we also considered the $\mathrm{Hg}^{2+}$ cation. The optimized stucture with $\mathrm{Hg}^{2+}$ in the centroid is unstable and dissociates $(-98 \mathrm{kcal} / \mathrm{mol})$. However, a stationary point with a stable structure appears with $\mathrm{Hg}$ at $z=1.34 \AA$, and pyramidal $\mathrm{C}_{3 \mathrm{v}}$ structure (Figure $4 \mathrm{a},-156 \mathrm{kcal} / \mathrm{mol}$ ), which is $58 \mathrm{kcal} / \mathrm{mol}$ lower with respect to the unbound system. This host $\cdots$ guest complex has Au-Hg distances of $2.76 \AA$, close to both covalent and ionic bonds (2.68 and $2.67 \AA$, respectively). ${ }^{[14,15]}$ Since the $\mathrm{Hg}$ atom overhangs in this compound, we consider an additional host structure forming a new adduct with the formula $\left[\mathrm{Hg}\left\{\mathrm{Au}_{3} \mathrm{Cage}_{3}\right\}_{2}\right]^{4-}$ (Figure $4 \mathrm{~b}$ ), analogous to those found for other spacer groups bewteen gold atoms as imino, ${ }^{[17]}$ pyrazol ${ }^{[18]}$ or imidazol. ${ }^{[19]}$ This sandwich-type compound should be stable with a pseudooctahedral environment for the mercury atom, and six $\mathrm{Au}-\mathrm{Hg}$ distances of $3.17 \AA$, larger than those found in $\left[\left\{\mathrm{Au}_{3} \mathrm{Cage}_{3}\right\}(\mathrm{Hg})\right]^{-}$as expected when increasing the number of chemical bonds. 


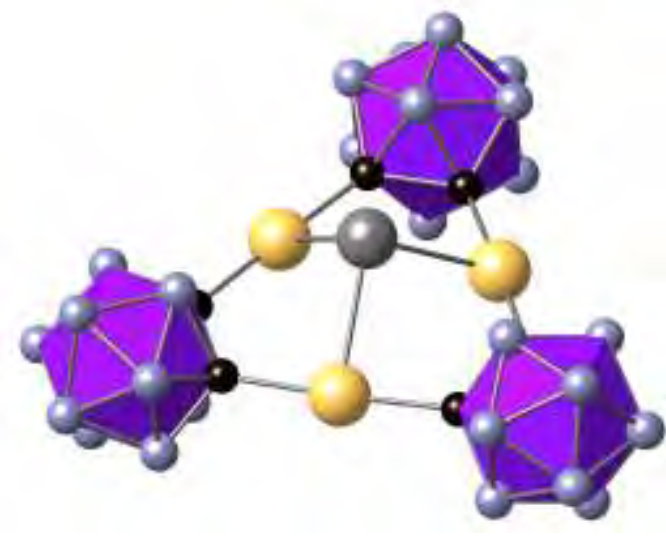

(a)

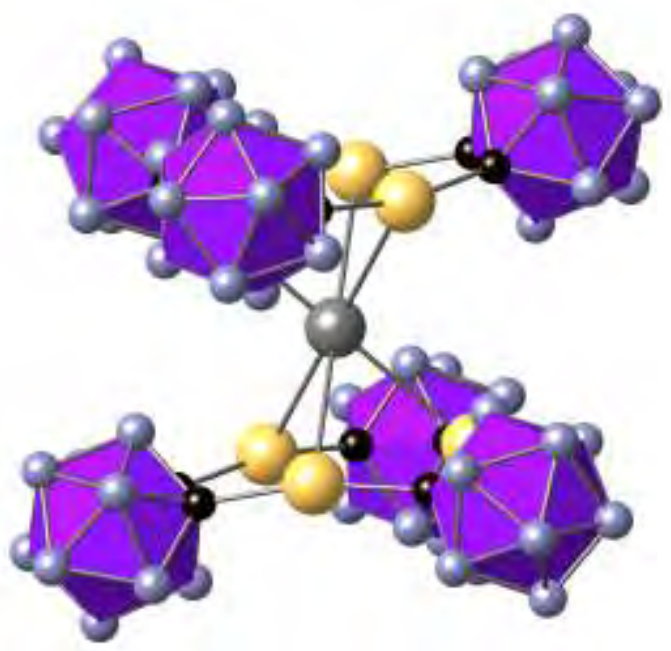

(b)

Figure 4. Optimized geometry for $(a)\left[\mathrm{Hg}\left\{\mathrm{Au}_{3} \mathrm{Cage}_{3}\right\}\right]^{-}$and $(b)\left[\mathrm{Hg}\left\{\mathrm{Au}_{3} \mathrm{Cage}_{3}\right\}_{2}\right]^{4-}$.

(b) Anions: Host $\cdots$ guest interactions are not only electrostatic. Therefore we have decided to insert some anions in the cavity of the gold triangle, following the example of experimental structures with neutral trinuclear complexes with halides ${ }^{[20]}$ or halocomplexes. ${ }^{[21]}$ We have studied the inclusion of halides $\left(\mathrm{F}^{-}, \mathrm{Cl}^{-}, \mathrm{Br}^{-}\right.$and $\left.\mathrm{I}^{-}\right)$; the further addition of hydride $\left(\mathrm{H}^{-}\right)$and acetylide $\left(\mathrm{HCC}^{-}\right)$is for comparative purposes. The computed energy profiles for these anions as function of $z$ is shown in Figure 5.

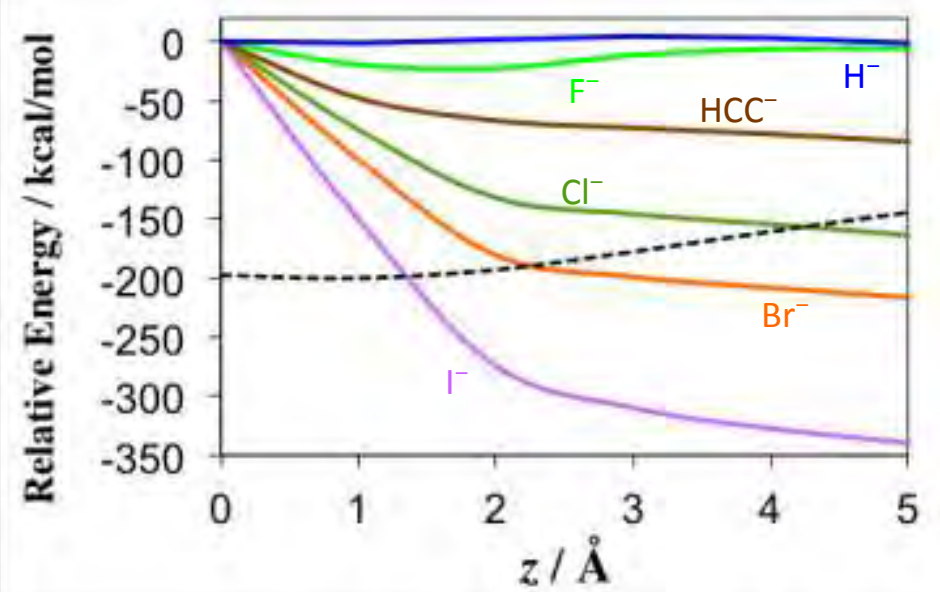

Figure 5. Energy profiles of host ${ }^{\cdots}$ guest interactions between $\left[\mathrm{Au}_{3} \mathrm{Cage}_{3}\right]^{3-}$ and different anions as function of $z$ : $\mathrm{H}^{-}, \mathrm{F}^{-}, \mathrm{Cl}^{-}, \mathrm{HCC}^{-}, \mathrm{Br}^{-}$, and $\mathrm{I}^{-}$. The electrostatic potential is represented with a dashed line. 
Unsurprisingly, all proposed adducts containing halides are repulsive and the most favoured structures do not have host $\cdots$ guest interactions. The order for the dissociation is the following: $\mathrm{F}^{-}<\mathrm{Cl}^{-}<\mathrm{Br}^{-}<\mathrm{I}^{-}$(about $-80,-250,-302$, and $-430 \mathrm{kcal} / \mathrm{mol}$, respectively), and can be related to the anion radii because the cavity has a reduced size for incorporating these anions. ${ }^{[15]}$ However, the instability of anion adducts rule out the formation of sandwich compounds, in comparason with neutral $\left\{\mathrm{Hg}_{3} \mathrm{Cage}_{3}\right\}$ systems, ${ }^{[22]}$ indicating that charged nature of the host play an important in the host $\cdots$ guest interactions.

A second mínimum is found for $\mathrm{F}^{-}$at $z=1.51 \AA$ (Figure 6a), confirmed by a full optimization. This geometry presents three Au-F distances of $2.65 \AA$, close to the sum of ionic radii ( $2.70 \AA$, in comparison to $1.93 \AA$ for a covalent bond), indicating the nature of the chemical bond. Moreover, fluoride has short contacts with three hydrogens of the carborane cage having $\mathrm{F} \cdots \mathrm{H}(\mathrm{B})$ distances of $2.81 \AA$, in contrast with negative-charged hydrogens for the expected polarity of hydrogen-boron bonds. However, the relative energy from the dissociated global mininum of $+57 \mathrm{kcal} / \mathrm{mol}$ together an estimated barrier about $18 \mathrm{kcal} / \mathrm{mol}$ suggests experimental difficulty for isolation. We should emphasize that similar distances for $\mathrm{F}^{-}(z=1.67 \AA)$ were found in interactions with the macrocycle complex $\left[\mathrm{Hg}_{3}\left(\mathrm{o}-\mathrm{C}_{6} \mathrm{~F}_{4}\right)_{3}\right] ;\left[{ }^{23}\right]$ note that the intermetallic distances in the $\left[\mathrm{Au}_{3} \mathrm{Cage}_{3}\right]$ and $\left[\mathrm{Hg}_{3}\left(\mathrm{o}-\mathrm{C}_{6} \mathrm{~F}_{4}\right)_{3}\right]$ are similar. We should also emphasize that $\left[\mathrm{Hg}_{3}\left(\mathrm{O}-\mathrm{C}_{6} \mathrm{~F}_{4}\right)_{3}\right]$ complexes with $\mathrm{Cl}^{-}$and $\mathrm{Br}^{-}$has macrocycle-anion distances of 2.3 $2.7 \AA$ which are exactly in the range of inflection point of the curves shown in Figure 5.

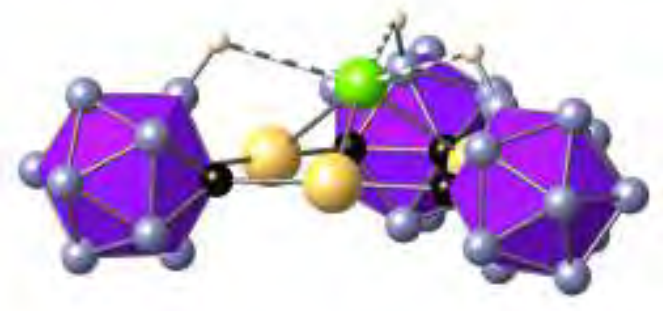

(a)

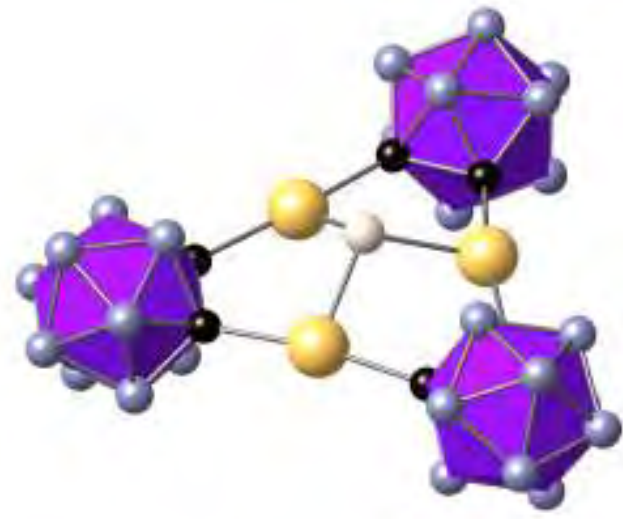

(b)

Figure 6. Optimized geometry for $\left[\left\{\mathrm{Cage}_{3} \mathrm{Au}_{3}\right\}(\mathrm{G})\right]^{3-}$, with $(a) \mathrm{G}=\mathrm{F}^{-}$and $(b) \mathrm{G}=\mathrm{H}^{-}$. 
Due to experimental data for late transition metal complexes interacting with borohydrides and polar boranes, ${ }^{[24]}$ we also included in the studies the hydride anion $\mathrm{H}^{-}$ as a guest. Again, the hydride adduct is repulsive and the dissociation is favoured with similar values as compared to $\mathrm{F}^{-}(\sim-73 \mathrm{kcal} / \mathrm{mol})$. Nevertheless, the host $\cdots$ hydride interaction becomes more attractive below $4 \AA$ with a minimum at $z=0.88 \AA$ with $\mathrm{C}_{3 \mathrm{v}}$ symmetry (Figure $6 \mathrm{~b}$ ) and $\mathrm{Au}-\mathrm{H}=2.29 \AA$. However, it is less stable than the unbound fragments by $69 \mathrm{kcal} / \mathrm{mol}$ with a meaningful barrier, suggesting that it is probably an unavalaible compound. Finally, the incorporation of acetylide along the $z$ axis of the host should be rejected, given the repulsive barrier. According to the size of the anions, the repulsive energy $(\sim-167 \mathrm{kcal} / \mathrm{mol})$ is intermediate between $\mathrm{F}^{-}$and $\mathrm{Cl}^{-}$anions.

(c) Neutral Molecules: Following our previous results for ions, we ask now if neutral molecules can be inserted in the host. As example, the neutral $\left\{\mathrm{Hg}_{3} \mathrm{Cage}_{3}\right\}$ host system crystalizes with solvent molecules as acetonitrile ${ }^{[25]}$ or water ${ }^{[26]}$ in which weak interactions between solvent and mercury are present. We are aware that interactions between the host and neutral guest can be very weak, and therefore a careful selection of molecules has been considered. We have selected single molecules combining different size, bonding and polarity, such as $\mathrm{H}_{2}, \mathrm{~N}_{2}, \mathrm{I}_{2}, \mathrm{C}_{2} \mathrm{H}_{2}, \mathrm{CO}$ and $\mathrm{CO}_{2}$. The computed energy profile along $z$ is presented in Figure 7 .

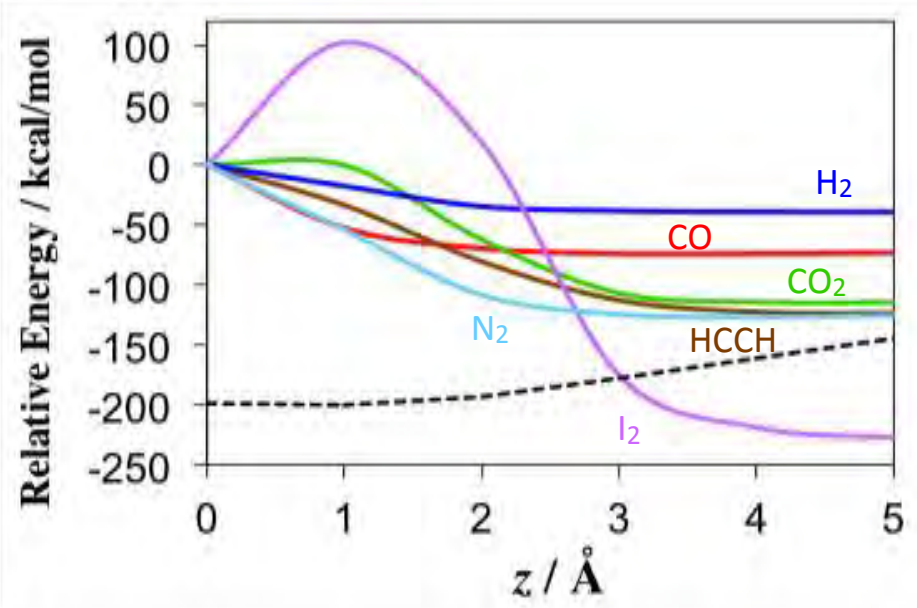

Figure 7. Energy profiles of host $\cdots$ guest interactions between $\left[\mathrm{Au}_{3} \mathrm{Cage}_{3}\right]^{3-}$ and different molecules: $\mathrm{H}_{2}$, $\mathrm{CO}, \mathrm{CO}_{2}, \mathrm{HCCH}, \mathrm{N}_{2}$, and $\mathrm{I}_{2}$. Electrostatic potential is also represented (dashed line). 
Inclusion complexes containing $\mathrm{H}_{2}, \mathrm{~N}_{2}, \mathrm{C}_{2} \mathrm{H}_{2}$, and $\mathrm{CO}$ are not formed. The small dihydrogen molecule is the less repulsive, according to size and poor electron density ($39 \mathrm{kcal} / \mathrm{mol})$. From the second period, triple-bonded molecules as dinitrogen and acetylene increase stability for unbound fragments with similar behavior (-127 and -123 $\mathrm{kcal} / \mathrm{mol}$, respectively). Even polar carbon monoxide is also repulsive, although less unfavoured than isolelectronic dinitrogen $(-72 \mathrm{kcal} / \mathrm{mol})$. Notice that these four molecules have the proper size, so that they could be inserted into the host void along $z$.

As displayed in Figure 7, carbon dioxide and diiodine show different behaviour, as compared to previous neutral molecules. Carbon dioxide is most favorable as unbound fragments (i.e. repulsive), but a second mimimum is obtained with $z=0 \AA$ with an energy diference of $115 \mathrm{kcal} / \mathrm{mol}$, hence suggesting that $\mathrm{CO}_{2}$ would form a stable adduct with carbon in the centroid of the gold host (Figure 8). Nevertheless, with a meaningful barrier of only few $\mathrm{kcal} / \mathrm{mol}$ suggesting some difficulty for isolation of the host $\cdots$ guest complex.

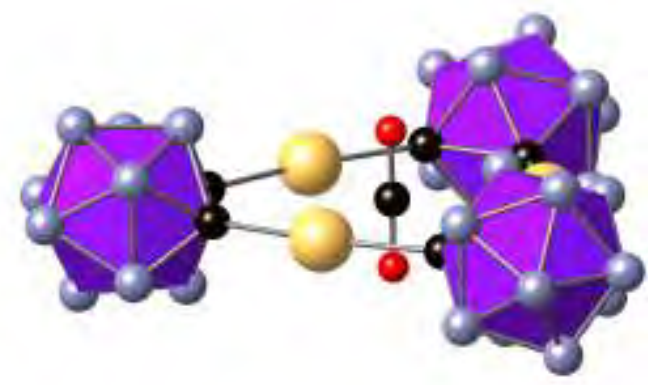

Figure 8. Optimized geometry of the adduct $\left[\left\{\mathrm{Au}_{3} \mathrm{Cage}_{3}\right\}\left(\mathrm{CO}_{2}\right)\right]^{3-}$.

Finally, the diiodine molecule appears to be a good candidate to be inserted in the centroid of the host, with an energy barrier about $103 \mathrm{kcal} / \mathrm{mol}$, although unbound fragments are most stable again $(\sim 230 \mathrm{kcal} / \mathrm{mol})$. However, $\mathrm{I}_{2}$ reacts with the host resulting into a $\mathrm{I} \cdots \mathrm{I}$ distance of $4.58 \AA$ ! Since diiodine is now reduced to iodide, the host is two-electron oxidized given formally "[$\left[\mathrm{Au}_{3} \mathrm{Cage}_{3}\right]$ ". Nevertheless, the final product has lost two electrons from the carboranes keeping the $\mathrm{Au}(\mathrm{I})$ centers $(\mathrm{Au}-\mathrm{I}=$ $3.15 \AA$ ), with $\mathrm{D}_{3 \mathrm{~h}}$ symmetry. Consequently, it should be rejected as a host $\cdots$ guest complex. 


\section{Conclusions}

Icosahedral carborane ligands turn out to combine with late transition metals (in this case Au to form stable metal complexes, whose voids can act as host structures for obtaining a variety of inclusion compounds with charged and neutral species. Different cations, anions and neutral molecules have been studied as guests to provide a general approach of host $\cdots$ guest interactions in these species. As example, electrostatic contribution is not only responsible of the formation, and adducts can be stabilized by covalent or weak non-bonding interations. As expected, cations as $\mathrm{Hg}^{2+}, \mathrm{Be}^{2+}$ or $\mathrm{H}^{+}$are good candidates to obtain these adducts. Specially relevant are the a priori unexpected stable compounds of the triply negative charged triangular gold structure with $\mathrm{F}^{-}$and $\mathrm{H}^{-}$. Finally, adduct with neutral $\mathrm{CO}_{2}$ could be available.

\section{Acknowledgmets}

J.M.O-E. is grateful to program "Salvador de Madariaga" from Spanish Ministerio de Educación, Cultura y Deporte (PRX17/00488). Financial support was provided from the Spanish Ministerio de Economía y Competitividad (CTQ2015-64579-C3-1-P).

Keywords: Host-Guest Systems ; Carboranes ; Quantum Chemistry

\section{References}

\footnotetext{
${ }^{1}$ J.-P- Sauvage, P. Gaspard (Eds), From Non-Covalent Assemblies to Molecular Machines, Wiley-VCH, Weinheim, 2011.

${ }^{2}$ M. A. Carvajal, J. J. Novoa, S. Alvarez, J. Am. Chem. Soc. 2004, 126, 1465-1477.

3 a) J. M. Oliva, N. L. Allan, P. v. R. Schleyer, C. Viñas, F. Teixidor, J. Am. Chem. Soc. 2005, 127, 13538-13547; b) H. Jude, H. Disteldorf, S. Fischer, T. Wedge, A. M. Hawkridge, A. M. Arif, M. F. Hawthorne, D. C. Muddiman, P. J. Stang, J. Am. Chem. Soc. 2005, 127, 12131.

${ }^{4}$ F. Teixidor (Ed), Recent Advances in Boron Chemistry, J. Organomet. Chem. 2009, 694, 1587-1780.

${ }^{5}$ M. F. Hawthorne, J. I. Zink, J. M. Skelton, M. J. Bayer, C. Liu, E. Livshits, R. Baer, D. Neuhauser, Science 2004, 303, 1849-1851.

${ }^{6}$ O. Crespo, M. C. Gimeno, A. Laguna, I. Ospino, G. Aullón, J. M. Oliva, Dalton Trans. 2009, 38073813.

${ }^{7}$ G. Aullón, A. Laguna, J. M. Oliva, Dalton Trans. 2012, 41, 14146-14150.

${ }^{8}$ O. Crespo, C. Diez-Gil, M. C. Gimeno, A. Laguna, M. Monge, I. Ospino, Dalton Trans. 2011, 40, 10038-1046.

${ }^{9}$ M. J. Frisch, G. W. Trucks, H. B. Schlegel, G. E. Scuseria, M. A. Robb, J. R. Cheeseman, G. Scalmani, V. Barone, B. Mennucci, G. A. Petersson, H. Nakatsuji, M. Caricato, X. Li, H. P. Hratchian, A. F. Izmaylov, J. Bloino, G. Zheng, J. L. Sonnenberg, M. Hada, M. Ehara, K. Toyota, R. Fukuda, J. Hasegawa, M. Ishida, T. Nakajima, Y. Honda, O. Kitao, H. Nakai, T. Vreven, J. A. Montgomery Jr., J. E. Peralta, F. Ogliaro, M. Bearpark, J. J. Heyd, E. Brothers, K. N. Kudin, V. N. Staroverov, R. Kobayashi, J. Normand, K. Raghavachari, A. Rendell, J. C. Burant, S. S. Iyengar, J. Tomasi, M. Cossi, N. Rega, J. M.
} 
Millam, M. Klene, J. E. Knox, J. B. Cross, V. Bakken, C. Adamo, J. Jaramillo, R. Gomperts, R. E. Stratmann, O. Yazyev, A. J. Austin, R. Cammi, C. Pomelli, J. W. Ochterski, R. L. Martin, K. Morokuma, V. G. Zakrzewski, G. A. Voth, P. Salvador, J. J. Dannenberg, S. Dapprich, A. D. Daniels, Ö. Farkas, J. B. Foresman, J. V. Ortiz, J. Cioslowski, D. J. Fox, Gaussian 09, Revision D.01, Gaussian, Inc., Wallingford CT, 2009.

${ }^{10}$ a) A. D. Becke, J. Chem. Phys. 1993, 98, 5648-5652; b) C. Lee, W. Yang, R. G. Parr, Phys. Rev. B 1988, 37, 785-789.

${ }^{11}$ P. J. Hay, W. R. Wadt, J. Chem. Phys. 1985, 82, 299-310.

12 a) P. C. Hariharan, J. A. Pople, Theoret. Chim. Acta 1973, 28, 213-222; b) M. M. Francl, W. J. Pietro, W. J. Hehre, J. S. Binkley, M. S. Gordon, D. J. DeFrees, J. A. Pople, J. Chem. Phys. 1982, 77, 36543665 .

13 a) P. J. Hay, W. R. Wadt, J. Chem. Phys. 1985, 82, 284-298. b) C. E. Check, T. O. Faust, J. M. Bailey, B. J. Wright, T. M. Gilbert, L. S. Sunderlin, J. Phys.Chem. A 2001, 105, 8111-8116.

14 B. Cordero, V. Gómez, A. E. Platero-Prats, M. Revés, J. Echeverría, E. Cremades, F. Barragán, S. Alvarez, Dalton Trans. 2008, 2832-2838.

15 a) R. D. Shannon, C. T. Prewitt, Acta Cryst., Sect. B 1969, 25, 925-946; b) R. D. Shannon, Acta Cryst., Sect. A 1976, 32, 751-767.

${ }^{16}$ a) E. Hupf, E. Lork, S. Mebs, J. Beckmann, Inorg. Chem. 2015, 54, 1847-1859; b) E. Hupf, R. Kather, M. Vogt, E. Lork, S. Mebs, J. Beckmann, Inorg. Chem. 2016, 55, 11513-11521.

17 A. Burini, R. Bravi, J. P. Fackler Jr., R. Galassi, T. A. Grant, M. A. Omary, B. R. Pietroni, R. J. Staples, Inorg. Chem. 2000, 39, 3158-3165.

${ }^{18}$ W.-X. Ni, Y.-M. Qiu, M. Li, J. Zheng, R. W.-Y. Sun, S.-Z. Zhan, S. W. Ng, D. Li, J. Am. Chem. Soc. 2014, 136, 9532-9535.

${ }^{19}$ a) T. Osuga, T. Murase, M. Fujita, Angew. Chem. Int. Ed. 2012, 51, 12199-12201; Angew. Chem. 2012, 124, 12365-12367; b) S. Suzuki, T. Wada, R. Tanimoto, M. Kozaki, D. Shiomi, K. Sugisaki, K. Sato, T. Takui, Y. Miyake, Y. Hosokoshi, K. Okada, Angew. Chem. Int. Ed. 2016, 55, 10791-10794; Angew. Chem. 2016, 128, 10949-10952.

${ }^{20}$ V. B. Shur, I. A. Tikhonova, A. I. Yanovsky, Y. T. Struchkov, P. V. Petrovskii, S. Y. Panov, G. G. Furin, M. E. Vol'pin, J. Organometallic Chem. 1991, 418, C29-C32.

${ }^{21}$ A. A. Titov, E. A. Guseva, O. A. Filippov, G. M. Babakhina, I. A. Godovikov, N. V. Belkova, L. M. Epstein, E. S. Shubina, J. Phys. Chem. A 2016, 120, 7030-7036.

${ }^{22}$ H. Lee, C. B. Knobler, M. F. Hawthorne, J. Am. Chem. Soc. 2001, 123, 8543-8549.

${ }^{23}$ K. I. Tugashov, D. A. Gribanyov, F. M. Dolgushin, A. F. Smol'yakov, A. S. Peregudov, M. K. Minacheva, I. A. Tikhonova, V. B. Shur, Organometallics, 2016, 35, 2197-2206.

24 a) L. N. Saitkulova, E. V. Bakhmutova, E. S. Shubina, I. A. Tikhonova, G. G. Furin, V. I. Bakhmutov, N. P. Gambaryan, A. L. Chistyakov, I. V. Stankevich, V. B. Shur, L. M. Epstein, J. Organometallic Chem. 1999, 585, 201-210; b) E. S. Shubina, I. A. Tikhonova, E. V. Bakhmutova, F. M. Dolgushin, M. Y. Antipin, V. I. Bakhmutov, I. B. Sivaev, L. N. Teplitskaya, I. T. Chizhevsky, I. V. Pisareva, V. I. Bregadze, L. Epstein, V. B. Shur, Chem. Eur. J. 2001, 7, 3783-3790; c) V. N. Tsupreva, O. A. Filippov, A. A. Titov, A. I. Krylova, I. B. Sivaev, V. I. Bregadze, L. M. Epstein, E. S. Shubina, J. Organometallic Chem. 2009, 694, 1704-1707; d) V. N. Tsupreva, O. A. Filippov, F. M. Dolgushin, K. I. Tugashov, A. I. Krylova, V. I. Bragin, I. A. Tikhonova, V. B. Shur and L. M. Epstein, E. S. Shubina, Russ. Chem. Bull. 2008, 57, 2540-2547; e) A. A. Titov, E. A. Guseva, A. Smol'yakov, F. M. Dolgushin, O. A. Filippov, I. E. Golub, A. I. Krylova, G. M. Babakhina, L. M. Epstein, E. S. Shubina, Russ. Chem. Bull. 2013, 62, 1829-1834.

25 a) X. Yang, Z. Zheng, C. B. Knobler, M. F. Hawthorne, J. Am. Chem. Soc. 1993, 115, 193-195; b) A. A. Zinn, Z. Zheng, C. B. Knobler, M. F. Hawthorne, J. Am. Chem. Soc. 1996, 118, 70-74.

${ }^{26}$ H. Lee, C. B. Knobler, M. F. Hawthorne, Angew. Chem. Int. Ed. 2001, 40, 3058-3060; Angew. Chem. 2001, 113, 3148-3150. 


\section{Tables of Contents (TOC)}

\section{Topic: Host $\cdots$ Guest Interactions}

A computational study of a cyclic trinuclear gold(I)-orto-carborane trianion acting as a host toward several different guest species of cations, anions, and neutral molecules is performed. The evaluation of energetic profiles have helped us to determine the capability of host $\cdots$ guest interactions, resulting in attractive profiles for some unexpected anions $\left(\mathrm{H}^{-}\right.$and $\left.\mathrm{F}^{-}\right)$and the $\mathrm{CO}_{2}$ molecule.

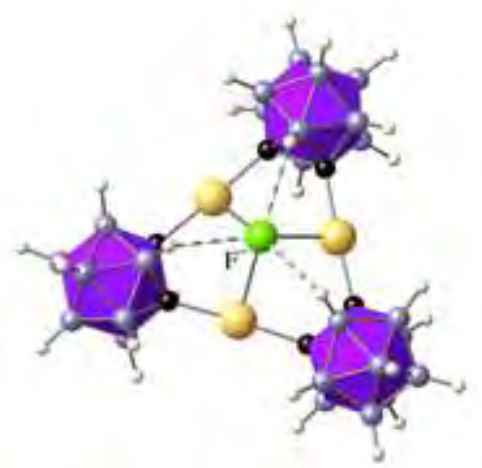

